\title{
First record of the genus Prosopistoma Latreille, I833 (Ephemeroptera, Prosopistomatidae) in Taiwan
}

\author{
Rita S. W. Yam' \\ I Department of Bioenvironmental Systems Engineering, National Taiwan University, Taipei 10617, Taiwan \\ R.O.C. \\ Corresponding author: Rita S.W.Yam (ritayam@ntu.edu.tw)
}

Academic editor: E. Dominguez | Received 21 October 2014 | Accepted 16 December 2014 | Published 20 January 2015

http://zoobank.org/48597AE6-6882-4FCA-B256-82F24E89E6C1

Citation: Yam RSW (2015) First record of the genus Prosopistoma Latreille, 1833 (Ephemeroptera, Prosopistomatidae) in Taiwan. ZooKeys 473: 147-156. doi: 10.3897/zookeys.473.8787

\begin{abstract}
The finding of three immature nymphs of Prosopistoma Latreille, 1833 (Ephemeroptera, Prosopistomatidae) in an upstream site of Baishih River represents the first record of this rarely collected genus in Taiwan. These nymphs were discovered through extensive monthly sampling at the riffle habitats from 13 undisturbed sites over two years (Dec 2008-Nov 2010). The coloration pattern of the collected immature nymphs in Taiwan is similar to the immature stage of $P$. ocellatum and $P$. annamense, two species which have been found in similarly undisturbed, upland forested-stream habitats.
\end{abstract}

\section{Keywords}

Mayfly, Prosopistomatidae, new record, nymph, morphology, Taiwan

\section{Introduction}

The Prosopistomatidae is a monogeneric family of Ephemeroptera, and is considered as rarely collected. At present, more than 20 known species of Prosopistoma Latreille, 1833 have been described from the Palaearctic, Oriental, Australasian, and Afrotropical regions (see review by Barber-James 2009, Shi and Tong 2013). The Oriental region (12 species) represents the most species-rich area for this genus (Lieftinck 1932, Peters 1967, Liu et al. 1984, Soldán and Braasch 1984, Tong and Dudgeon 2000, Sartori 
and Gattolliat 2003, Zhou and Zheng 2004, Barber-James et al. 2008, Barber-James 2009, Shi and Tong 2013). No Prosopistoma has been mentioned in Taiwan despite records of this genus in the nearby continental China and other major Asian Pacific islands (e.g. Philippines, Borneo, Java and Sumatra).

Studies on the diversity of mayfly in Taiwan started from Ulmer (1912) who mentioned nine species with decription of four new species of Ephemera, Isonychia and Ecdyonurus. The taxonomic records of mayfly extensively increased in 1990's (e.g. Kang and Yang 1994a, b, c, d, e, 1995, 1996a, b, Kang et al. 1994, Bae 1997) when 45 species of Ameletidae, Baetidae, Heptageniidae, Leptophlebiidae and Caenidae were described from more than 100 localities (see review in Soldán and Yang 2003). To date, at least 65 species (28 genera and 9 families) of mayflies are recorded in Taiwan (Soldán and Yang 2003). However, no Prosopistoma has been discovered in Taiwan in the last $>100$ years of entomological studies, suggesting its rarity in Taiwan. The present study is to report the first record of Prosopistoma in Taiwan and consequently its geographic extension in the Oriental region.

\section{Materials and methods}

Extensive monthly surveys for benthic macroinvertebrates at the riffle habitats from 13 undisturbed, upland sites of the Baishih River from the Water Resource Protection Area of the Feitsui Reservoir in New Taipei City, Taiwan were conducted for two years from Dec 2008 to Nov 2010 (Fig. 1). Prosopistoma nymphs were only discovered at the study site BA1 (Fig. 2), and samples were collected using hand nets from the stony streambed. All materials were collected by the author, and preserved in $95 \%$ ethanol. The specimens were examined and dissected under stereomicroscopes. The dissected mouthparts and legs were investigated using a compound light microscope. One specimens were air-dried, gold coated and examined using a Scanning Electron Microscope. All specimens are kept in the Ecology and Conservation Laboratory, Department of Bioenvironmental Systems Engineering, National Taiwan University, Taiwan (ECL). Terminology follows Kluge (2004) and Barber-James (2010).

\section{Taxonomy}

Family Prosopistomatidae Lameere, 1917

Genus Prosopistoma Latreille, 1833

\section{Prosopistoma sp.}

Figs 3-6

Material examined. ECL-20100701-1: 1 nymph, TAIWAN, Baishih River $\left(24.882695^{\circ} \mathrm{N}, 121.656242^{\circ} \mathrm{E}\right), 1 . v i i .2010$. ECL-20100707-2: 1 nymph, TAIWAN, 


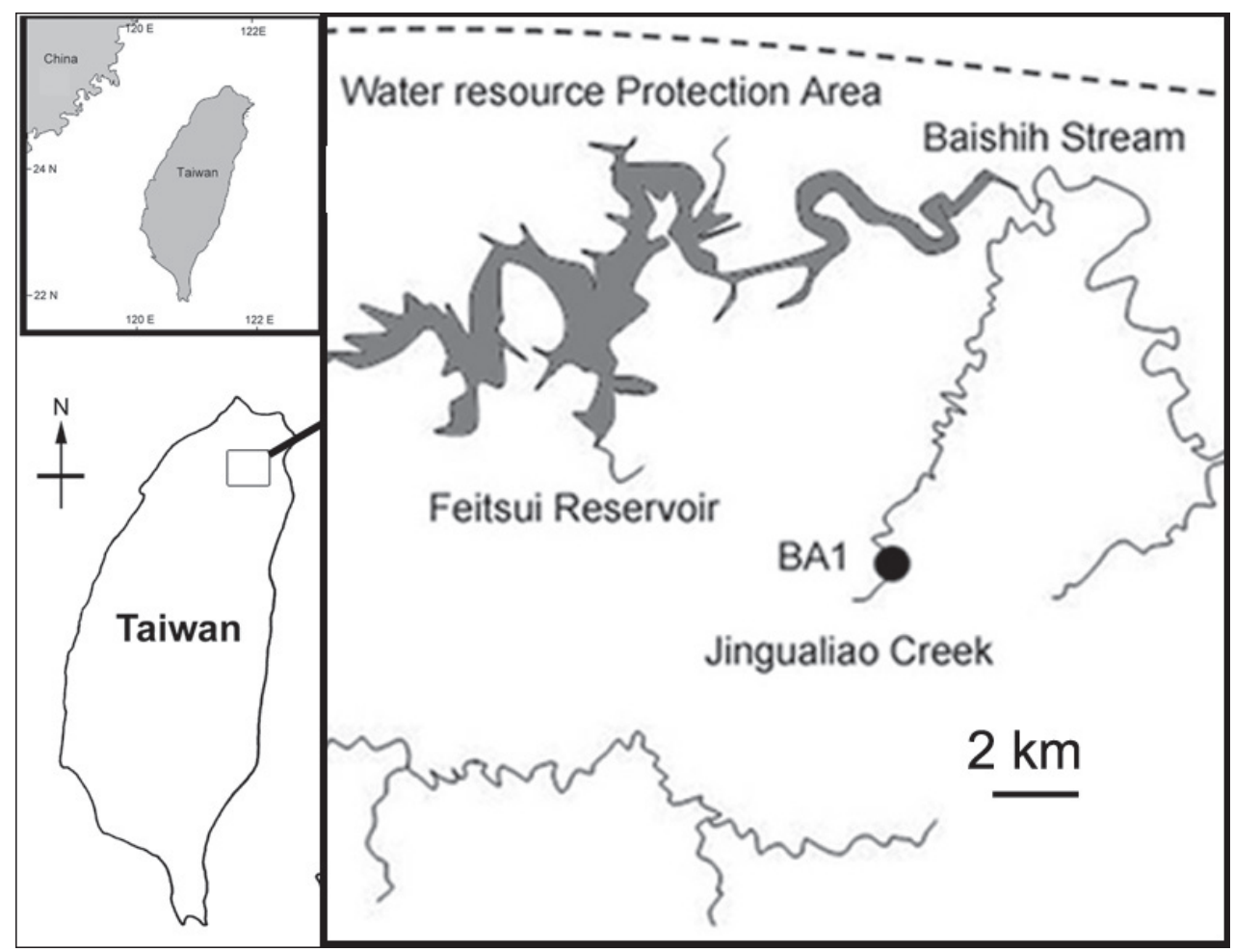

Figure I. Map of Taiwan showing location of the study area. BA1 represents the collection site for Prosopistoma sp.

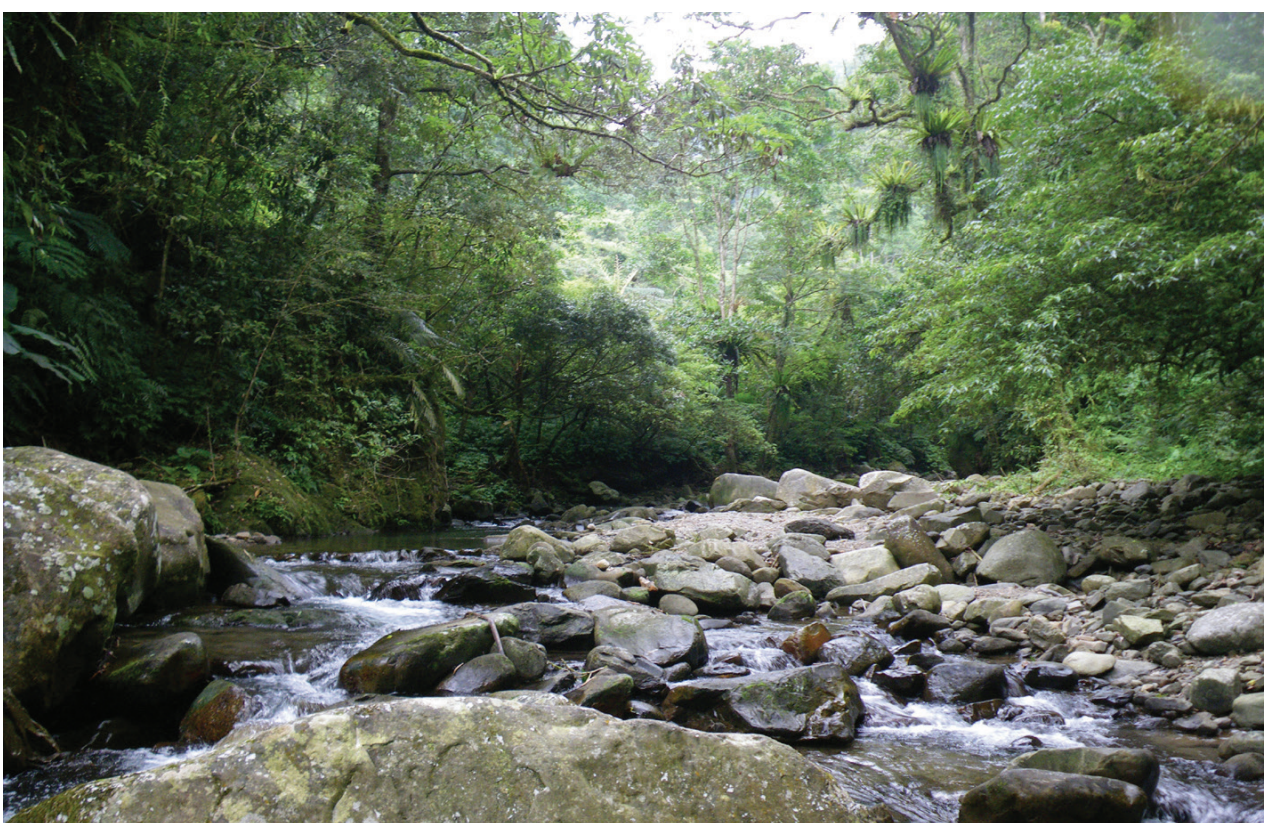

Figure 2. Photograph of the collection site BA1. 


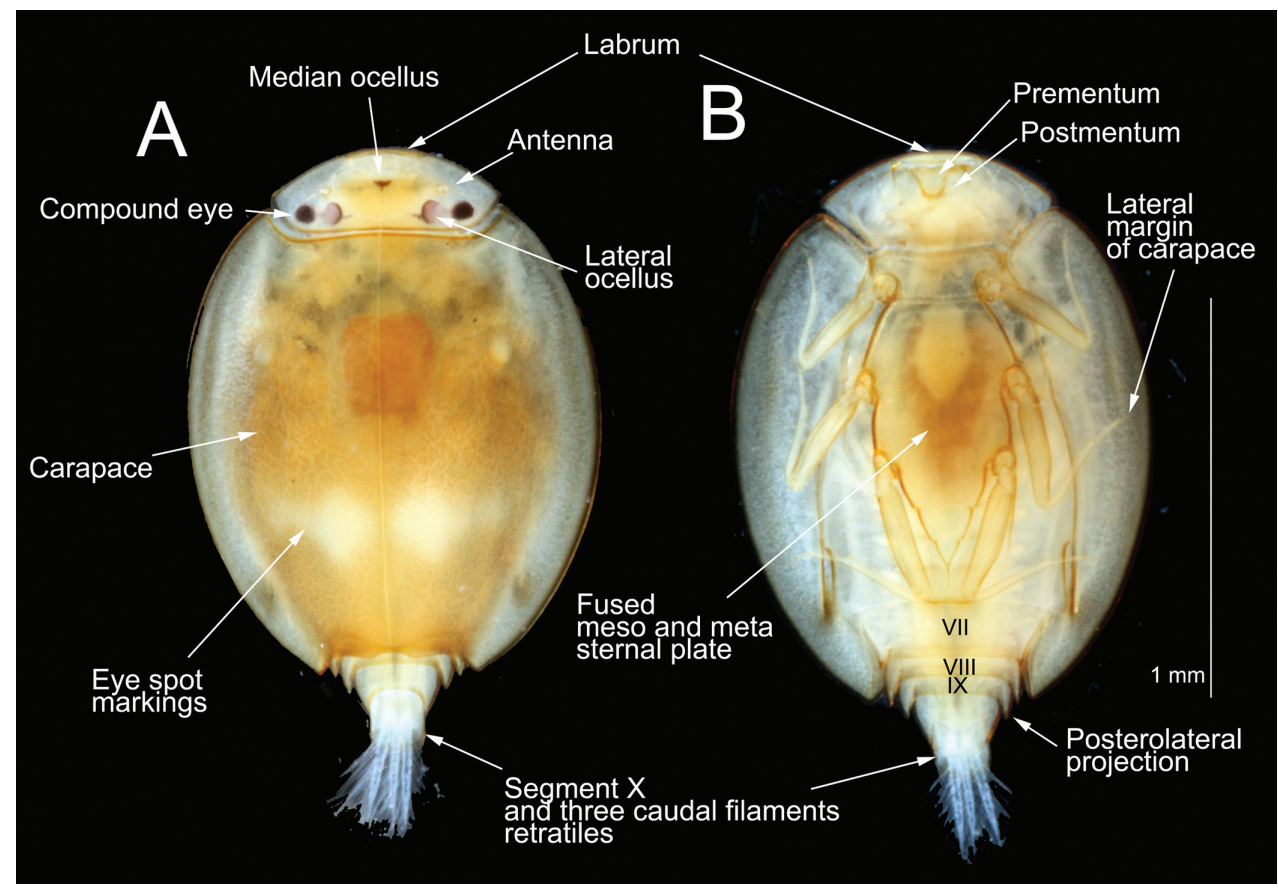

Figure 3. Prosopistoma sp. whole nymph: A Dorsal view B Ventral view.

Baishih River $\left(24.882695^{\circ} \mathrm{N}, 121.656242^{\circ} \mathrm{E}\right)$, 7.vii.2010. ECL-20100707-3: same data as ECL-20100707-2.

Description. Immature nymph. Body length $1.5-2 \mathrm{~mm}$, excluding caudal filaments. Head yellowish with a small red median ocellus, width about 3 times longer than length. Carapace coloration orange, with two white eye-spot markings on each side close to the mid line, about $2 / 3$ of the distance from the base of the head. Distal end of carapace with a concave exhalent notch (Fig. 3A-B).

Head. Antenna with 5 segments, segment III longest (Fig. 4A). Labrum narrow, 3 times wider than long, surface with stout setae, anterior margin with sparse setae (Fig. 4B). Left and right mandibles similar, outer canine longer than the inner one, outer canine with three apical teeth, outer tooth the smallest with smooth outer margin, inner tooth the largest, with three short spines along the inner margin. Inner canine with two apical teeth, inner tooth larger with outer margin smooth, inner margin with two small spines. Two smooth setae below the inner tooth (Figs.4C-D). A single simple seta present lateromedially on each mandible (Fig. 4C). Maxillae with1 rigid canine at tip, with 3 subequal dentisetae and 3 stout setae (Fig. 4E-F). A simple seta at 2/3 of the sclerotized section of galea-lacinia (Fig. 4E-F). Maxillary palp 3-segmented, with segment II the longest (Fig. 4E). Labium composed of prementum and postmentum. Prementum trapezoid, cutting edge with fine teeth (Fig. 4G). Postmentum with large notch, to house the prementum (Fig. 4H). Labial palp 3-segmented, with the second the longest (Fig. 4G). 

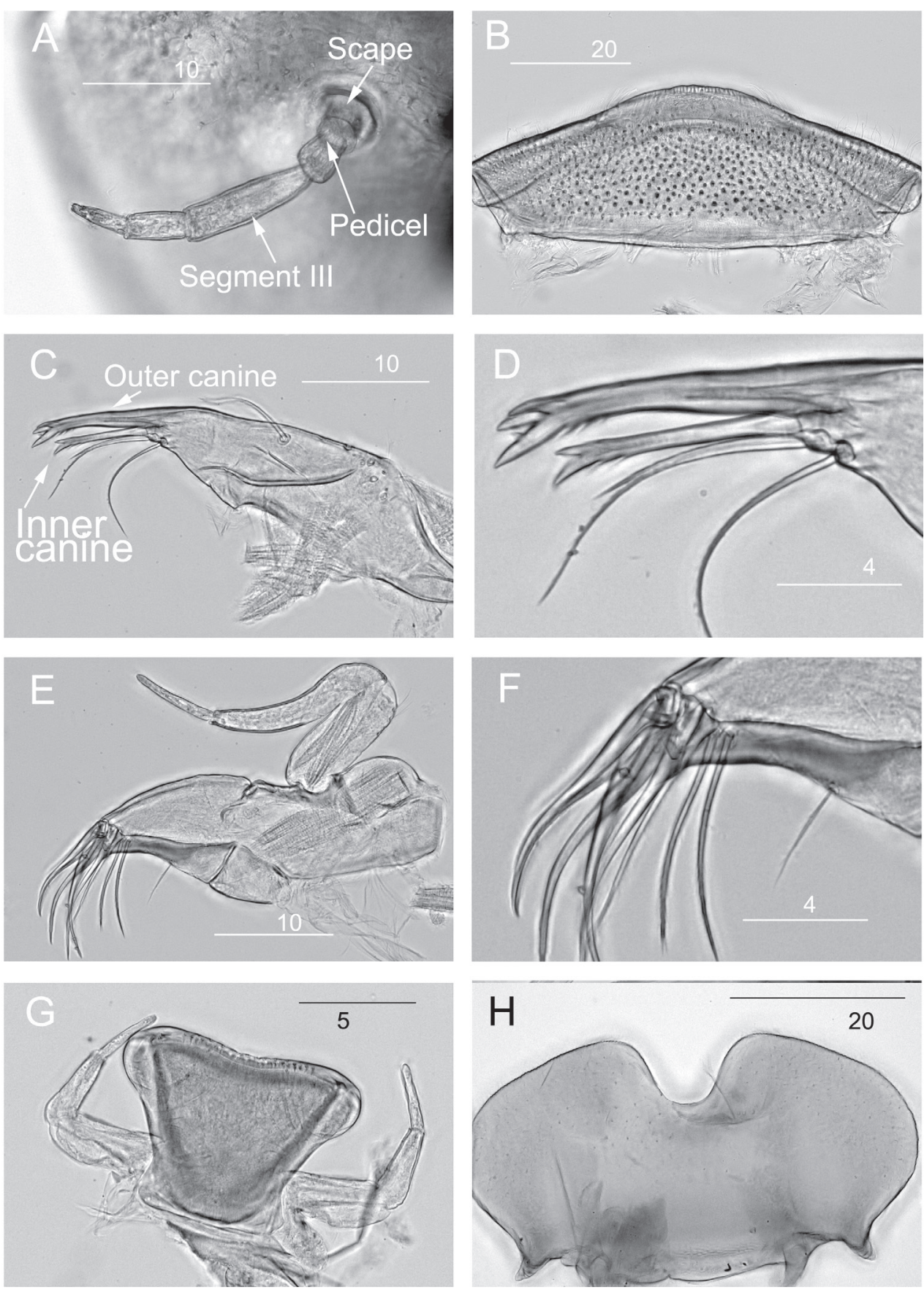

Figure 4. Prosopistoma sp.: A Antenna B Labrum C Mandible D Magnified view of inner and outer canine of mandible $\mathbf{E}$ Maxillae $\mathbf{F}$ Tip of Maxillae $\mathbf{G}$ Prementum with labial palps $\mathbf{H}$ postmentum. Scale bar in $\mu \mathrm{m}$. 

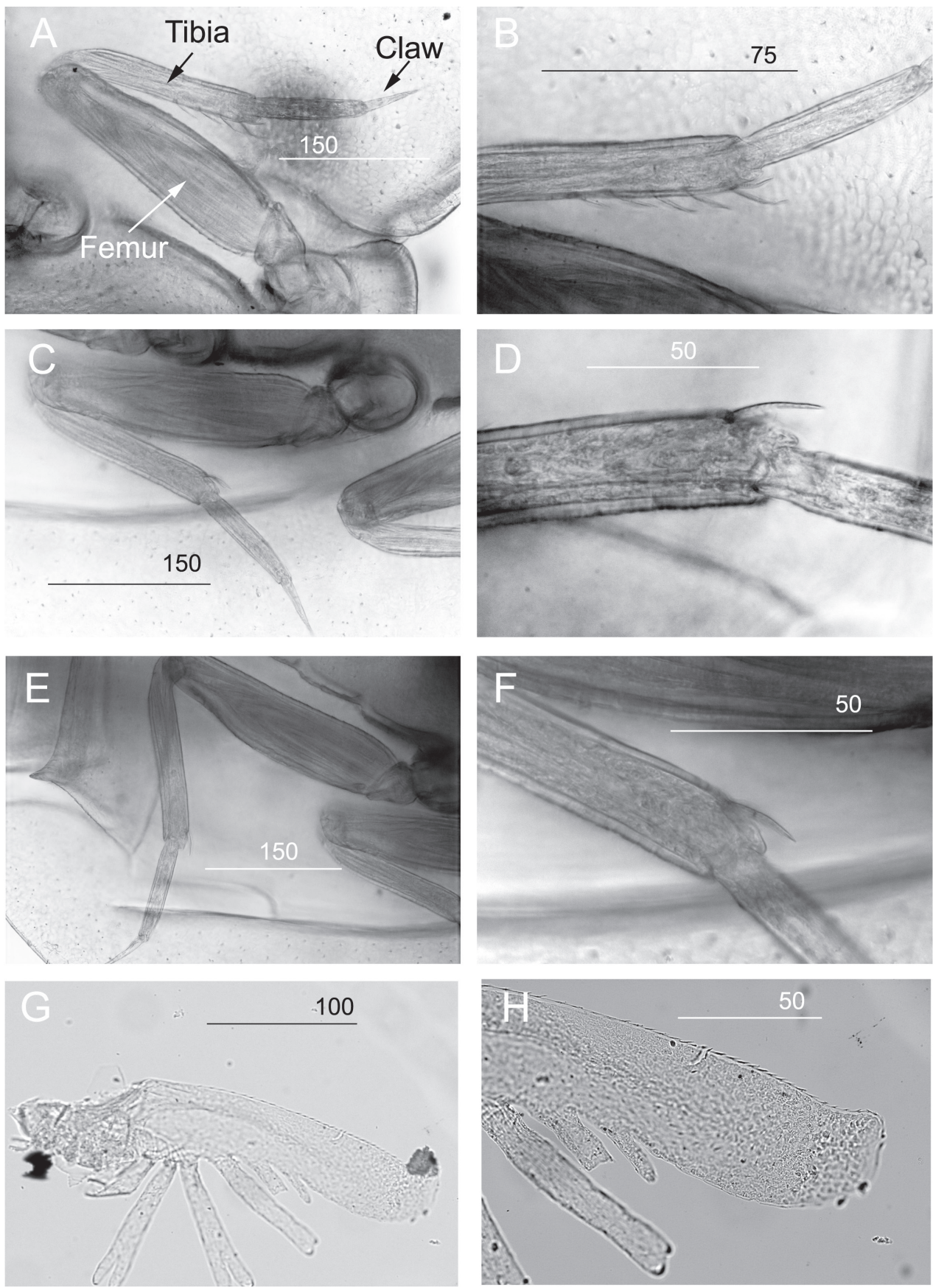

Figure 5. Prosopistoma sp.: A Leg I B Apex of ventral margin of tibia showing 4 serrated spines C Leg II D Apex of ventral margin of tibia of leg II E Leg III F Apex of ventral margin of tibia of leg III G Gill I $\mathbf{H}$ Upper lamellae portion of gill I. Scale bar in $\mu \mathrm{m}$. 
Legs. Dorsal and ventral margins of fore femur smooth (Figs 5A, 6A). Ventral margin of fore tibia with a row of 4 serrated setae (Figs 5B, 6C). Apical serrated setae on tibiae of legs II and III (Figs 5D, F, 6B, E-H). Claws of all legs sharp and without denticles (Fig. 6D).

Abdomen. Posterolateral projections of abdominal segments VII-IX sharp and with pointed apex (Fig. 3B). Three caudal filaments short and setose (Fig. 3B). Gill I with long upper lamellate portions, lamellate margin serrated, lower portions divided into several branches (Fig. 5G-H). Gill II leaf-like unbranched. Gill VI tiny, unbranched.

Distribution. At present, this unnamed species is only recorded in Baishih River from Taiwan.

Habitat. The collection site BA1 is an undisturbed forested-stream (356 m a.s.l., Fig. 2) with wetted width $(6.3-10.5 \mathrm{~m})$ and depth $(0.2-0.7 \mathrm{~m})$ relatively constant throughout the year. This site is generally oligotrophic (nitrate-nitrogen $<0.01 \mathrm{mg} / \mathrm{L}$, ammonium-nitrogen $=1.40 \pm 0.28 \mathrm{mg} / \mathrm{L}$, total phosphorus $=0.10 \pm 0.06 \mathrm{mg} / \mathrm{L}$ ). Nymphs were found within the riffles with accumulated leaf packs on the bed substrates dominated by gravels and pebbles, moderate to high current velocity (26.7$65.1 \mathrm{~cm} / \mathrm{s})$ and high dissolved oxygen level $(7.3-9.6 \mathrm{mg} / \mathrm{L})$. Nymphs were rare and they contribute to the relative composition of the mayfly community by $0.19 \%$ during the study period. Dominant families of mayfly nymphs collected in the same habitat included Baetidae, Heptageniidae, Leptophlebiidae and Caenidae.

Remarks. According to the diagnostic key in Shi and Tong (2013), the immature nymphs of Prosopistoma sp. are morphologically similar to $P$. ocellatum. The coloration pattern of the collected immature nymphs in Taiwan is similar to the immature stage of $P$. ocellatum and $P$. annamense. However, as the important diagnostic characteristics, such as number of setae on fore tibia and number of antennal segments, are likely to change with ontogenetic shift, we cannot properly diagnose our specimens due to the lack of mature nymphs collected through extensive sampling in the present study.

Habitat of the nymphs of Prosopistoma sp. are similar to most Prosopistoma such as $P$. annamense, $P$. olympus and $P$. ocellatum. Their habitats are generally located in the undisturbed upstream site (altitude $=200-800 \mathrm{~m}$ a.s.l.) commonly characterized by stony streambed, shallow water depth, and moderate to high current velocity (Soldán and Braasch 1984, Sartori and Gattolliat 2003, Shi and Tong 2013) except that nymphs of $P$. annamense were recorded in the large urban river Xiangjiang from China (Liu et al. 1984).

In this study, the finding of three immature nymphs of Prosopistoma sp. from the upstream site of Baishih River represents the first record of this rarely collected genus in Taiwan. Thus, further collections should be conducted at more river sites to obtain the mature nymphs to ascertain the taxonomic status of this Prosopistoma sp. in Taiwan. 

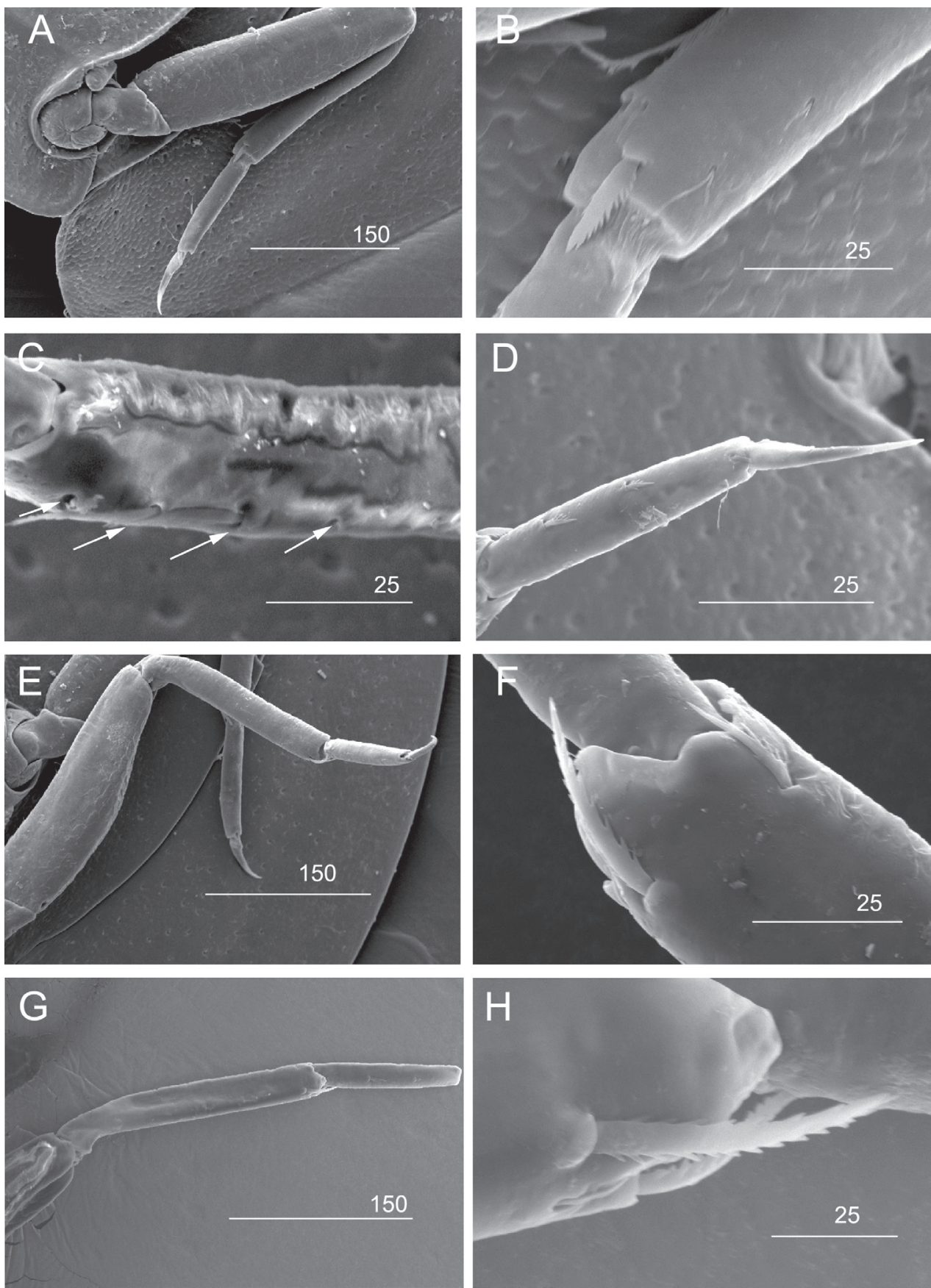

Figure 6. SEM of Prosopistoma sp.: A Leg I B Dorsal margin of tibia of leg I C Ventral margin of tibia of leg I, showing 4 serrated spines (indicated by white arrows). Note spines 1 and 4 are broken $\mathbf{D}$ Claw of leg I E Leg II F Fore-tibia of leg II G Leg III H Apex of fore-tibia of leg III. Scale bar in $\mu \mathrm{m}$. 


\section{Acknowledgements}

This study was supported by the research grants 100-2410-H-002-196-MY3 and 1012923-I-002 -001-MY2 from the Ministry of Science and Technology of Taiwan. The author would like thank the Editor, Dr. Michel Sartori and Dr. Janice Peters for their constructive comments on the manuscript. Special thanks go to Kari Feng for her technical assistance. The Agriculture Department from the New Taipei City Government was also acknowledged for issuing the field sampling permit at the Baishih River during the study period.

\section{References}

Bae YJ (1997) A historical review of Ephemeroptera systematics in the Northeast Asia. In: Landolt P, Sartori M (Eds) Ephemeroptera \& Plecoptera: Biology-Ecology-Systematics. MTL, Fribourg, 405-417.

Barber-James HM, Gattolliat JL, Sartori M, Hubbard MD (2008) Global diversity of mayflies (Ephemeroptera, Insecta) in freshwater. Hydrobiologia 59: 339-350. doi: 10.1007/ s10750-007-9028-y

Barber-James HM (2009) A preliminary phylogeny of Prosopistomatidae (Ephemeroptera) based on morphological characters of the larvae, and an assessment of their distribution.

Aquatic Insects 31: 149-166. doi: 10.1080/01650420903020502

Barber-James HM (2010) Neotype erection, redescription of the larva and first description of the winged stages of Prosopistoma variegatum Latreille, 1833 (Insecta: Ephemeroptera) from Madagascar. Aquatic Insects 32: 215-243. doi: 10.1080/01650424.2010.506691

Kang SC, Chang HC, Yang CT (1994) A revision of the genus Baetis in Taiwan (Ephemeroptera, Baetidae). Journal of Taiwan Museum 47: 9-44.

Kang SC, Yang CT (1994a) The nymph of Isonychia formosana (Ulmer, 1912) (Ephemeroptera, Oligoneuriidae). Journal of Taiwan Museum 47: 1-3.

Kang SC, Yang CT (1994b) Heptageniidae of Taiwan (Ephemeroptera). Journal of Taiwan Museum 1: 5-36.

Kang SC, Yang CT (1994c) Leptophlebiidae of Taiwan (Ephemeroptera). Journal of Taiwan Museum 47: 57-82.

Kang SC, Yang CT (1994d) Three new species of the genus Ameletus from Taiwan (Ephemeroptera: Siphlonuridae). Chinese Journal of Entomology 14: 261-269.

Kang SC, Yang CT (1994e) Ephemeroidea of Taiwan (Ephemeroptera). Chinese Journal of Entomology 14: 391-399.

Kang SC, Yang CT (1995) Ephemerellidae of Taiwan (Insecta, Ephemeroptera). Bulletin of the National Museum of Nature and Science 5: 95-116.

Kang SC, Yang CT (1996a) Two new species of Baetis Leach (Ephemeroptera: Baetidae) from Taiwan. Chinese Journal of Entomology 16: 61-66. 
Kang SC, Yang CT (1996b) A new species of Caenis Stephens (Ephemeroptera: Caenidae) from Taiwan. Chinese Journal of Entomology 16: 55-59.

Kluge NJ (2004) The Phylogenetic System of Ephemeroptera. Kluwer Academia Publishers, Dordrecht, 442 pp. doi: 10.1007/978-94-007-0872-3

Lieftinck MA (1932) A new species of Prosopistoma from the Malay Archipelago (Ephemeropt.). Tijdschrift voor Entomologie (supplement) 75: 44-55.

Liu B, Wang S, Hu D (1984) An evaluation on pollution in the Xiang Jiang River by using zoobenthos. Acta Hydfrobiol Sin 8: 225-236.

Peters WL (1967) New species of Prosopistoma from the Oriental Region (Prosopistomatidae: Ephemeroptera). Tijdschrift voor Entomologie 110: 207-222.

Sartori M, Gattolliat JL (2003) First record and new species of the genus Prosopistoma Latreille, 1833 (Ephemeroptera, Prosopistomatidae) from Borneo (East Kalimantan, Indonesia). Mitteilungen der Schweizerischen Entomologischen Gesellschaft 76: 301-305.

Shi W, Tong X (2013) A new species of Prosopistoma (Ephemeroptera: Prosopistomatidae) from China with a key to Oriental species. Zootaxa 3718: 89-096. doi: 10.11646/ zootaxa.3718.1.8

Soldán T, Braasch D (1984) Two new species of the genus Prosopistoma (Ephemeroptera: Prosopistomatidae) from Vietnam. Acta Entomology of Bohemoslovaca 81: 370-376.

Soldán T, Yang JT (2003) Mayflies (Ephemeroptera) of Taiwan: Species composition, taxonomic shifts, distribution and biogeographical analysis. In: Gaino E (Ed.) Research Updates on Ephemeroptera and Plecoptera. Perugia, 413-419.

Tong XL, Dudgeon D (2000) A new species of Prosopistoma from China (Ephemeroptera: Prosopistomatidae). Aquatic Insects 22: 122-128. doi: 10.1076/0165-0424(200004)22:2;1P;FT122

Ulmer G (1912) H. Sauter's Formosa-Ausbeute. Ephemeriden. Entomologische Mitteilungen 1: 369-375.

Zhou CF, Zheng LY (2004) The genus Prosopistoma from China, with descriptions of two new species (Ephemeroptera: Prosopistomatidae). Aquatic Insects 26: 3-8. doi: 10.1076/ aqin.26.1.3.35375 